\title{
Ritual Circumcision in the Age of Germ Theory Amongst Nineteenth-Century New York Immigrants
}

\author{
DANIEL B. POLIAK* \\ Albert Einstein College of Medicine of Yeshiva University, 1925 Eastchester Road \#3G, Bronx, \\ New York, NY 10461, USA
}

\begin{abstract}
While Jewish ritual circumcision continues to be a controversial issue in Europe and the US, metzitzah b'peh, the addendum to brit milah, which requires the mohel (ritual peritomist) to orally suck blood from the wound immediately following the excision of the foreskin, remains a divisive topic. While medical historians have studied European outbreaks of infectious disease following metzitzah b'peh, no one has assessed the response of the nineteenth century New York Jewry. This paper analyses how this nascent community responded to the thorough report by the New York Board of Health following an alleged and discredited outbreak of syphilis attributed to metzitzah b'peh in 1873, especially in the context of nineteenth century immigration, popular perception of syphilis and American medicine.
\end{abstract}

Keywords: Ritual Circumcision, Metzitzah b'peh, Syphilis, Syphilophobia, Mohel, Lower East Side

\section{Introduction}

Metztizah b'peh is an addendum to ritual circumcision, which requires the mohel (ritual circumciser, plural: mohalim) to orally suck blood from the wound immediately following the excision of the foreskin. Predicated upon Hellenistic theories of pathophysiology, it was an established therapeutic and post-operative healing method established by the first-century AD. ${ }^{1}$ In recent years, many have vociferously contended over the value and suitability of the rite. Metzitzah b'peh has evolved since the mid-nineteenth century, such that devices (eg. glass tubes) have been employed which retain the spirit of the rite but provide safety by preventing contact between the mohel's lips and the wound. Currently, mohalim either perform the traditional rite with or without direct oral contact (by utilising a glass tube), or abstain from the practice altogether. Numerous times since 2000, the

\footnotetext{
*Email address for correspondence: daniel.poliak@med.einstein.yu.edu
}

I wish to thank Dr Edward Reichman for providing me with advice and crucial primary and secondary sources. Anonymous reviews of this journal provided with thought-provoking feedback and suggestions which helped me re-assess my research. I would also like to thank my wife, Jennifer Poliak, for her continual support and love. Segments of this article have been adapted and modified from my previous article in Tradition ('Metsitsah be-Peh, Nineteenth Century New York Jewry, and the Board of Health', Tradition, 44, 3 (2011), 39-52.)

${ }^{1}$ For an overview of the proposed therapeutic mechanisms and historical perspectives of metzitzah b'peh, see Shlomo Sprecher, 'Meziòzaòh be-Peh—Therapeutic Touch' Hòakirah (2006), 23-29. 
New York City Health Commissioner investigated the aetiology of reported cases of genital herpes simplex virus type 1 which appeared in Jewish male infants following the application of metzitzah b'peh. ${ }^{2}$ This outbreak prompted a renewed interest in the act which is now limited to small segments of the Jewish population. ${ }^{3}$

Since the eighteenth century, rabbis, physicians, communal leaders and government officials have quarrelled over the efficacy and safety of metzitzah b'peh. As recent as 2012, reports of infectious disease attributed to the rite prompted New York City officials to enact legislation requiring parents to provide written consent before metzitzah b'peh is performed. New York politicians have contended with safety of metzitzah b'peh for over a century, as the first investigation dates to 1873 .

Under the guidance of Dr Robert W. Taylor, the New York Board of Health studied a markedly similar cluster of ill infants who were initially thought to have contracted syphilis. ${ }^{4}$ An examination of the 1873 New York episode provides insight into the relationship between this immigrant ethnic community and health officials in an age when germ theory was becoming more accepted. The nascent Jewish community's response to the recommendations and observations posed by the New York City Board of Health reveals how religious tolerance was perceived amongst these late-nineteenthcentury immigrants. By exploring the historical context of this little-known outbreak and investigation, I hope to demonstrate how differences in religious tolerance and medical knowledge caused this case to differ from its European counterparts.

\section{Taylor's 1873 Investigation}

By 1873, Eastern European Jewish immigrants were settling in the densely populated Lower East Side. According to census reports, the mostly immigrant neighbourhoods south of 14th Street housed a population of 497289 (equivalent to 52.77\% of Manhattan's population), of which 285445 individuals resided in the eastern district, which included the predominantly Jewish Lower East Side. ${ }^{5}$ Reports indicate that by 1880, 60000 Jews resided in New York City, ${ }^{6}$ and the densely populated Lower East Side's infamous tenement houses proved to be a breeding ground for infectious diseases. ${ }^{7}$

After Dr Abraham Jacobi notified the City Sanitary Inspector that syphilis befell four otherwise healthy Jewish boys who were ritually circumcised by the same mohel over the course of four months, the Board of Health established an inquiry to determine the

\footnotetext{
${ }^{2}$ Susan Blank et al., 'Neonatal Herpes Simplex Virus Infection Following Jewish Ritual Circumcisions That Included Direct Orogenital Suction - New York City, 2000-2011', Morbidity and Mortality Weekly Report, 61, 22 (2012), 405-9.

${ }^{3}$ Janice H. Tanne, 'Ultra-Orthodox Jews Criticized over Circumcision Practice', BMJ 332 (2006), 137. Tanne reports that estimates range from 2000 to 4000 metzitzah b'peh cases occur each year in New York City.

${ }^{4}$ R.W. Taylor, 'On the Question of the Transmission of Syphilitic Contagion in the Rite of Circumcision', New York Medical Journal (1873), 561-82.

${ }^{5}$ Board of Health of the Health Department of the City of New York Fourth Annual Report (New York: D. Appleton and Company, 1874), 144.

${ }^{6}$ Lance J. Sussman, Jewish History Resources in New York State from the State Archives. (Binghamton, New York: New York State Archives Partnership Trust, 1999); Jacob Rader Marcus, United States Jewry, 1776-1985, Vol. 1. (Detroit: Wayne State University Press, 1989), 12. Rader Marcus cites historians who claim that 12000 of these Jews were Russian or Polish immigrants.

${ }^{7}$ For a comprehensive illustration of the public health hazards of the Lower East Side two decades later, see Howard Markel, Quarantine! East European Jewish Immigrants and the New York City Epidemics of 1892 (Baltimore: Johns Hopkins University Press, 1997).
} 
aetiology of this cluster. ${ }^{8}$ The Board assigned the laborious task to Dr Robert W. Taylor, the Surgeon to the New York Dispensary and Department of Venereal and Skin Diseases, who had previously examined two of the babies who had elusive lesions and symptoms. On 10 June 1873, Taylor presented his findings to the New York Board of Health, and later published the account in an article titled, On the Question of the Transmission of Syphilitic Contagion in the Rite of Circumcision.

In 1873 it was not yet known that Treponema pallidum was the causative agent of syphilis and the disease's plethora of manifestations made an accurate diagnosis difficult. ${ }^{9}$ However, nineteenth century physicians recognised the sexual transmission of syphilis and had established its stages of development. Taylor would incorporate this rudimentary medical knowledge to determine the cause of death in the three circumcised infants.

While initially the physicians suspected that the one infant who recovered and the three that died all contracted syphilis, Taylor was sceptical of an outbreak of syphilis amongst infants, since he conceded that 'recorded cases of primary syphilitic lesions of the genital organs of the infant are as yet so few in number', and as such he lacked a 'systematic description' of juvenile syphilis. ${ }^{10}$ The dearth of syphilis records was not unique to the paediatric population, since in 1873 American public health officials abstained from 'applying quarantine or disinfection measures' to stymie the spread of syphilis because 'the prevailing social mores prohibited any public effort' ${ }^{11}$ This policy promulgated the notion that 'the sexual character of these infections cast them beyond the pale; they were considered the wages of sin, and the fact that there were innocent victims was simply disregarded'. ${ }^{12}$ American officials ignored reality since throughout history, syphilis has indiscriminately ravaged society, as 'with a democratic tread' it has penetrated 'all walks and stations in life, laying out alike royalty or the vagrant, the curled-haired and slasheddoubleted (sic) knight, or the tonsured monk' ${ }^{13}$

The low reported incidence of syphilis also contributed to Taylor's hesitation to immediately accept the diagnosis. Despite the laissez faire attitude towards syphilis prevention and containment, the Board of Health's annual report stated that in 1873 there were 160 deaths attributed to syphilis. ${ }^{14}$ However, due to the disregard for venereal diseases, this figure might not represent the actual number of deaths, since the disease of 'the derelicts and alcoholics' might have been underreported. ${ }^{15}$ Syphilophobia was also endemic in America, and the disease was considered to be God's punishment for evildoers. ${ }^{16}$ Due to the stigma of syphilis, an 1883 textbook of the venereal disease pathology written by Taylor admitted that official figures do not convey the reality since 'the unfortunate victims, although innocent, are usually most careful to conceal their

${ }^{8}$ While Taylor did not identify Jacobi as the primary physician, in 26 January 1895 letter to the Medical Record, Dr Henry Levien stated that Jacobi examined the infants, and notified the authorities.

${ }^{9}$ Markel Howard, When Germs Travel (New York: Pantheon Books, 2004), 153.

10 Taylor, op. cit. (note 4), 567.

11 John Duffy, A History of Public Health in New York City 1886-1966 (New York: Russel Sage Foundation, 1974), 166.

12 Ibid.

${ }^{13}$ Peter Charles Remondino, History of Circumcision from the Earliest Times to the Present (Philadelphia: The Medical Bulletin Printing House, 1891), 187.

14 Board of Health of the Health Department of the City of New York op. cit. (note 5), 181.

${ }^{15}$ Duffy, op. cit. (note 11), 166.

16 Vern L. Bullough, Sexual Variance in Society and History (Hoboken, NJ: Wiley, 1976), 552. 
misfortune'. ${ }^{17}$ Comparatively large European cities in the nineteenth century reported many more cases of syphilis. For instance, in 1851, $13.5 \%$ of the ill in Berlin had syphilis. ${ }^{18}$

Compounded with this oversight was the distrust and fear of the medical establishment harboured by many immigrants. ${ }^{19}$ The immigrants' perception of physicians is best illustrated by Jacob Riis in his famed portrayal of Lower East Side tenement life, How The Other Half Lives, wherein the immigrants would 'hide their sick lest the authorities carry them off to the hospital to be slaughtered' ${ }^{20}$ It is therefore probable that the actual occurrences of syphilis belie the official reports.

The low prevalence of syphilis amongst New York Jewry might have also initially dissuaded Taylor from assuming that the infants were stricken with syphilis. Despite the medical establishment's disdain for the unsanitary conditions and habits of the Lower East Side's Jewish residents, many physicians conceded that the incidence of syphilis amongst Jews was comparatively less than that of the population at large. For instance, The Journal of Cutaneous Diseases, published a letter from an attending at 'the Good Samaritan Dispensary, where the patients are mostly of the Jewish persuasion', who reported that 'syphilitic and gonorrheal patients, proportionately taken, show an unusually small number which are affected with syphilis'. ${ }^{21}$ In addition, Remondino asserted that on a whole, since Jewish 'women have abstained from vice', they 'are as a class free from any syphilitic taint'. 22 Remondino also provided empirical evidence from Metropolitan Free Hospital in London's Jewish quarter, where the ratio of Jewish syphilitic patients to gentile syphilitic patients was one to fifteen. ${ }^{23}$ While the Jewish immigrant population did have a lower incidence of venereal disease than neighbouring groups, the Lower East Side's thriving prostitution industry did cause the incidence of such diseases to rise. ${ }^{24}$ It must be reiterated that while some erroneously claimed that circumcision provided immunity to syphilis and lauded the benefits of circumcision, in reality, ethical standards and expectations which condemned promiscuity contributed to the lower incidence of venereal diseases amongst Jews. ${ }^{25}$ With all of these considerations, Taylor approached the investigation sceptical of his colleagues' conclusions.

Taylor found that 'after circumcision by a Hebrew named $\mathrm{H}-$ ', the four infants 'were attacked by phagedenic ulceration of the penis, and by lesions of the skin and lymphatic ganglia', which resulted in the death of three of the four infants. ${ }^{26}$ The parents of all four infants were not syphilitic, and in the first two cases, Taylor ascertained that the parents

\footnotetext{
${ }^{17}$ Robert W. Taylor, The Pathology and Treatment of Venereal Diseases (Philadelphia: Henry C. Lea's Son \& Co, 1883), 464.

18 Remondino, op. cit. (note 13), 188.

${ }^{19}$ In When Germs Travel, op. cit. (note 9), Markel illustrates the precarious situation of twentieth and twentyfirst century indigent, and often undocumented, immigrants who are less likely than naturalised citizens to seek medical assistance.

20 Jacob Riis, How The Other Half Lives (New York: Charles Scribner's Sons, 1890), 109.

${ }^{21}$ Sol Rosenbaum, 'Correspondence: Circumcision - Syphilis', Journal of Cutaneous and Genito-Urinary Diseases, XVII, 7, (1899), 317.

22 Remondino, op. cit. (note 13), 191.

23 Ibid., 192.

${ }^{24}$ Deborah Dwork, 'Health Conditions of Immigrant Jews on the Lower East Side of New York: 1880-1914', Medical History, 25, 1 (1981), 31.

${ }^{25}$ Robert Darby, 'Where Doctors Differ: The Debate on Circumcision as a Protection Against Syphilis', Journal of the Society for the Social History of Medicine, 16, 1 (2003), 71-3.

26 Taylor, op. cit. (note 4), 563.
} 
were the primary caretakers, and he therefore excluded the possibility that the parents transmitted the disease. ${ }^{27}$

After establishing the commonalities, Taylor methodically detailed the particulars of each case. Of all four patients, it was only the first, Simon Gutmann, whom Taylor believed contracted syphilis. Following his circumcision on 8 May 1872, Gutmann's wound healed, but two months later a sore 'developed directly on the line of incision', and remained ulcerated and 'confined to that portion' for several months. ${ }^{28}$ These symptoms persisted through the end of the year, and when Taylor examined Gutmann in February 1873, the child had a 'well-marked papular syphilide' along his 'trunk, arms, and thighs'. ${ }^{29}$ These were accompanied by 'unmistakable lesions' along his penis, as well as 'a hard, indolent swelling' which 'presented that cartilaginous hardness peculiar to the Hunterian lesion', as observed in adult syphilis. ${ }^{30}$ These two signs, papular syphilide and Hunterian chancre, were recognised to be frequent initial indicators of syphilis. ${ }^{31}$ In addition, even though the two-month incubation period was unusually long, reports indicate that this latent segment can extend from four to one hundred days. ${ }^{32}$ Eventually, it was only Gutmann, the most likely syphilitic patient, who survived the fifteen-month bout.

In February 1873, prior to the establishment of the commission, Taylor examined the second ill infant, Harris Lewin, and challenged the claim that Lewin contracted syphilis. Similar to Gutmann, Lewin's wound healed and he was initially asymptomatic. However, two weeks following the circumcision, the infant developed an ulcer which persisted for eight months. At five months of age the infant was examined at the German Dispensary on East 3rd Street, and the ulcer and accompanying lymphatic swelling were drained. When Taylor was consulted, he found that the eight-and-half-month-old, 'thin, pale, delicate, weak, and very peevish' Lewin had superficial ulcerations along the penis, but was free of chancres and syphilitic lesions. ${ }^{33}$ The lack of conclusive syphilitic symptoms caused Taylor to exclude syphilis from his differential diagnosis. Rather, he speculated that the superficial nature, crustiness and progression of symptoms indicated that after a ninemonth period of unrelenting inflammation Lewin developed eczema. Lewin would become the first fatality and died of pneumonia at nine months of age.

Unlike the first two patients who initially recuperated from the procedure, Wolf Harris and William Simon's wounds never healed. Shortly after both circumcisions, each of their penises were infected and ulcerated, and Harris's eventually sloughed off, and he passed away at seven months of age. While Taylor never examined Harris, the attending physician, Dr Loewenthal, reported 'that diphtheritic ulceration and exhaustion were the causes of

\footnotetext{
27 Ibid., 563, 566.

28 Ibid., 577.

29 Ibid., 563.

${ }^{30}$ Ibid.

${ }^{31}$ Taylor, The Pathology and Treatment, op. cit. (note 18), 809; Samuel Cooper, 'Lectures on the Principles, Practice and Operations of Surgery - Venereal Diseases', London Medical and Surgical Journal, IV, 102 (1834), 739.

${ }^{32}$ When discussing the incubation time, Taylor wrote that usually in children, albeit in other parts of the body (mostly in and around the mouth), 'the syphilitic process, either by erosion, ulceration, or induration, develops itself within a fortnight after contagion' (op. cit., note 4, 568). Nowadays it is recognised that the chancre usually appears about three weeks after infection. In addition, tertiary syphilis, which is marked by nervous system disorders, occurs after a latent period which can persist for many years. See Eugene Nestor, Microbiology: A Human Perspective (McGraw-Hill), 633.

33 Taylor, op. cit. (note 4), 566.
} 
death' ${ }^{34}$ William Simon required two interventions to stymie the infection and was treated with anti-syphilitics, but he too died at seven months of age. ${ }^{35}$

Eventually, Taylor concluded that only Gutmann, the sole survivor, most certainly contracted syphilis, since the symptoms were such that 'no one at all familiar with syphilis could have mistaken it'. ${ }^{36}$ However, with regards to the following three infants, he suspected that 'the [mere] existence of lesions on the genital organs' and the accompanying suffering was hastily thought by some to 'have no other origin other than syphilis' ${ }^{37}$ Rather, Taylor contended that the abscesses were non-specific and occur in non-syphilitic children as well. ${ }^{38}$ Without the knowledge of Treponema pallidum, American physicians did not isolate the bacteria for diagnostic purposes, and syphilis was the 'presumptive diagnosis of many genital lesions'. ${ }^{39}$ Therefore, Dr Edward Reichman has postulated that these infants, as well as the many others in Europe who succumbed to metzitzah b'peh related illnesses, might have contracted other diseases besides syphilis. In light of the $21 \mathrm{st}$ century outbreaks, Reichman suggested that the infants contracted herpes simplex virus, thereby absolving the mohel of promiscuity.

Based on the relevant medical histories, Taylor confidently argued against the presence of syphilis in three of the four patients. However, to thoroughly investigate the deaths, Taylor turned his attention to the circumcision instruments, participants, procedure and protocol. The mohel was amenable to the investigation, and he presented Taylor with the surgical instruments and materials in their usual state, all of which Taylor found to be satisfactorily clean. This allowed Taylor to conclude that the instruments used were not the fomites in question. ${ }^{40}$

Taylor was familiar with reported outbreaks of syphilis following metzitzah b'peh, and understood that if the mohel had any lesions or excoriations in his throat or mouth, then he could have imparted a disease. ${ }^{41}$ Therefore, after excluding the possibility of contaminated material, Taylor inquired whether the mohel performed metzitzah b'peh. $\mathrm{H}$ - was an experienced, elderly, mohel who by his own account performed three thousand circumcisions. He conceded that while he had once performed metzitzah b'peh with regularity, he now seldom performed the rite. The mohel then consulted his records to reveal 'that during the four months in question, he had performed the rite eight times, inclusive of the cases under consideration'. ${ }^{42}$ By the mohel's own admission, at least two

\footnotetext{
${ }^{34}$ Ibid. Taylor contended that there was no evidence for the presence of a diphtheritic ulceration, and if it had existed 'it would in all probability have proved rapidly fatal' (570).

35 Ibid., 567.

36 Ibid., 572.

37 Ibid., 562.

38 Ibid., 570.

${ }^{39}$ Edward Reichman, 'Metzitzah b'peh: A Medical Historical Note', Association of Orthodox Jewish Scientists Intercom, XXV, 3 (2005), 1-2.

${ }^{40}$ In Taylor's day, scientists argued about the ability to transmit syphilis without interpersonal physical contact. In fact, Taylor quoted a study which denied the ability for syphilis to spread via a contaminated object. However, in a footnote on page 577, Taylor contended that syphilis can be communicated in such a manner. Today it is acknowledged that it is almost exclusively transmitted by oral or sexual contact.

${ }^{41}$ For instance, in a footnote on page 578, Taylor cites 'Dr Kaposi's very elegant atlas of syphilis (Die Syphilis der Hautund der Augrenzenden Schleimhaute)' in which Kaposi 'gives the illustrations of two cases of Jewish children having ulcers on the penis' and were said to be caused by the circumcision. See W.H.A. Jacobson, The Diseases of the Male Organs of Generation. (Philadelphia: P. Blakiston, Son \& Co, 1893), 635-7 in which Jacobson provides a literature review of syphilis being spread by ritual circumcision both because of metzitzah b'peh, as well as by contaminated instruments.

42 Taylor, op. cit. (note 4), 576.
} 
of the other four infants were asymptomatic and otherwise healthy. Nonetheless, Taylor thoroughly examined $\mathrm{H}$ - and obtained a detailed medical history to determine whether he could have imparted syphilis. The examination concluded that $\mathrm{H}-$ was free of venereal diseases at the time of examination, and Taylor was unable to conclude that the mohel transmitted a particular illness.

Although Taylor exonerated the mohel, he recognised that metzitzah b'peh introduces a heightened risk of communicating disease, and emphatically called for its abolishment. After warning of the risks posed by metzitzah b'peh, Taylor introduced other suggestions to ensure the safety of circumcision. For instance, Taylor called for the 'removal of the privilege to perform the rite from the hands of the non-professionals who now so largely perform it', and to instead designate 'a delegation of responsible and educated persons' such as physicians who are adept in surgical hygiene. ${ }^{43}$ Aside from technique, Taylor contended that physicians must be present to intervene in the event of an accident.

The critical 21 st century reader of Taylor's report might wonder whether the article contains rhetorical overtones, and even outright disdain for the Jewish community, which would have prompted its representatives to have objected for being unjustifiably maligned. In fact, Taylor repeatedly refers to the Jews as 'a low and ignorant class of people', and even speculates that their tendencies to be 'careless, uncleanly (sic), and even filthy' contributed to the spread of disease. ${ }^{44}$

Taylor's depictions were consistent with the medical establishment's conception of the immigrant class, and he might have been even more sensitive and empathetic than his colleagues. For instance, in 1874, A.N. Bell, chairman of the Section on State Medicine and Public Hygiene and founding editor of The Sanitarian, notably referred to the tenement residents as 'troglodytes, living like moles and bats in the dark, poisoning the atmosphere around, and sucking the life-blood of the people'. ${ }^{45} \mathrm{He}$ also maligned these residents by claiming that 'such surroundings obtund and destroy human sensibilities' so they 'become an easy prey to the sensual excitements of alcohol and other debasing agencies and influences'. Bell concluded that 'the same broad road to disease and death is the highway to moral degradation'. While Bell accurately describes the dense, crimeridden and unhygienic conditions of the Lower East Side, less vitriolic health officials reported that disease rates were unexpectedly low amongst the Jewish immigrants residing in the Lower East Side, which they attributed to the population's rare alcoholism and social customs, including fastidious housekeeping. ${ }^{46}$

In fact, it was these tenements that Taylor visited to examine the ill infants. Wolf Harris, the seven month old who according to his physician succumbed to the effects of a diphtheritic ulceration, lived in the heart of the tenements on 65 Mott Street. Situated just south of Canal Street, the seven-storey walk-up built in 1824, claims to be the first building built intended to serve as a tenement house. ${ }^{47}$ With scores of families crowded into the 2450 square foot property's thirty-six two-bedroom apartments, 65 Mott Street served as an icon and 'living monument to the evils of the tenement system' ${ }^{48}$ Even the

43 Ibid., 580.

${ }^{4}$ Ibid., 563, 570.

45 A.N. Bell, 'The Waste of Life', Sanitarian, 2, 4 (1874), 147.

${ }^{46}$ Dwork, op. cit. (note 24), 25-30.

47 Tyler Anbinder, Five Points: the 19th-century New York City Neighborhood that Invented Tap Dance, Stole Elections, and became the World's Most Notorious Slum (New York: Simon and Schuster, 2001), 81.

${ }^{48}$ Ibid. When Anbinder described 65 Mott's living conditions, she reported that 'by the end of the nineteenth century, no other landlord in Five Points had the nerve to squeeze so many families into so small a space'. 
most dispassionate visitor in 1873 would have noticed the neighbourhood's decrepit and unsanitary conditions, and would have been repulsed by 65 Mott Street, 'the crowning glory of tenement houses' which in the 1880s The Times likened to 'a wart growing on the top of a festering sore'. 49

Moreover, any grievances with Taylor and his potential biases or allegiances should be neutralised by his balanced and conciliatory tone. For instance, throughout his illustration of metzitzah b'peh, Taylor never adopts a sensationalist approach like European physicians who routinely called it an unsightly rite, which 'affronts the eye of the expert as it does the emotions of the layman' ${ }^{50}$ Taylor also emphasises that metzitzah b'peh was not ubiquitous, but was 'nearly obsolete' even amongst 'the lower classes of Jews' ${ }^{51}$ In addition, by constantly differentiating between 'the lower orders' and 'the higher classes of Jews', Taylor attempts to frame his argument not in religious, but in socioeconomic terms. After calling for safety precautions, Taylor expressed his hope that such investigations would 'render a rite, which has useful sanitary bearings, less liable to fall into disrepute among those upon which it is obligatory'. 52 Thus, while some of Taylor's rhetoric would initially seem acrimonious, by placing the investigation in its historical context, any malice dissipates and Taylor remains a reliable and credible authority.

While Taylor repeatedly refers to the state of affairs in the Jewish community, he never indicates that he consulted its leaders or authorities. In fact, the only representative he reports to have met was the amenable mohel. Therefore, other sources must be sought to assess how the Jewish community responded to this meddling in their affairs, and if they considered it a maligning of their community.

After news reached communal leaders that the Board of Health investigated the hygiene of circumcision, one would have expected the rabbinic leaders to have responded. However, the remaining sermons, publications and correspondences do not indicate that the clergymen contended with the 1873 investigation.

Since rabbinic opinions have not been preserved for posterity, or perhaps the thenunorganised rabbinate did not even respond to the investigation and deaths, the Jewish press was responsible for sounding the clarion call for reform and oversight of circumcision. ${ }^{53}$ The Jewish Messenger stood out from other contemporaneous English Jewish periodicals, as it publicised the investigation by publishing three opinion articles regarding the 1873 investigation.

\section{The Jewish Messenger's Clarion Call}

Founded by Rev. Samuel Myer Isaacs in 1857, The Jewish Messenger was an early major Anglo-Jewish newspaper which represented the orthodox, anti-reform perspectives of its founder. ${ }^{54}$ The responses penned by Samuel Isaacs during the summer of 1873,

\footnotetext{
49 'Plumber and Sanitary Engineer.' The Times, 22 March 1880, quoted in Anbinder, op. cit. (note 47), 81.

${ }^{50}$ Kochbe Jizchak 1, no. 1 (1845): 38, quoted in Jacob Katz, Divine Law in Human Hands: Case Studies in Halakhic flexibility (Jerusalem: Magnes Press, 1998), 362.

51 Taylor, op. cit. (note 4), 573.

52 Ibid., 582. Taylor's seems to have had a positive disposition towards circumcision in general. Some of Taylor's colleagues advocated circumcision and attributed various, and even mysterious, homeopathic-like remedies to it.

${ }^{53}$ For an overview of rabbinic leaders at the time who could have responded, and assessment of the evolution of rabbinic communal leadership in light of this investigation, see this author's article 'Metsitsah be-Peh, Nineteenth Century New York Jewry, and the Board of Health', Tradition, 44, 3 (2011), 46-47, 51-52.

${ }^{54}$ Melvin Urofsky, American Zionism From Herzl to the Holocaust (Lincoln, Nebraska: University of Nebraska Press, 1995), 47; Naomi W. Cohen, What the Rabbis Said (New York: New York University Press, 2008), 54.
} 
portray the response of concerned citizens and the ineptitude of the rabbinic leaders. In the week following the publication of the Board of Health's investigation, The Jewish Messenger did not report the deaths or the investigation. In addition, based on The Jewish Messenger's later response, it appears that in the interim, representatives of the Jewish community did not publicly respond to the report. However, in the following week, two weeks after the publication of the investigation, Isaacs published a scathing article entitled 'Religious Wrongs', where he berated the Jewish leadership for their irresponsible appointment and regulation of religious functionaries. Isaacs deemed the Board of Health's reports, 'concerning the rite of circumcision by incompetent persons: men of doubtful moral character and of certain lack of knowledge', a 'scandal' which 'ought to rouse our ministers and our congregations'. ${ }^{55}$ Moreover, Isaacs wrote that this 'serious evil' besmirches Judaism, since 'men of dubious character dare to officiate at the solemn, important, and ancient ceremonial which has tended to preserve the purity of the race'. Isaacs also referred to 'the performance of the sacred rite by persons unfit to officiate' as a 'shameful evil', and a 'well founded charge of hypocrisy'. Two weeks later, Isaacs continued to lament the compromise on the 'purity of Israel's race', again alluding to the alleged moral degradation of religious functionaries. ${ }^{56}$ Although Taylor exonerated the mohel of communicating a venereal disease, by emphasising the mohel's 'dubious' and 'doubtful moral character', as well as 'the purity of the race', The Jewish Messenger insinuates that the mohel transmitted a venereal disease as a result of an allegedly licentious lifestyle. After not providing a tempered expose of the investigation and its subsequent report, and instead publishing numerous scathing op-eds, the conservative The Jewish Messenger did not assess the report's validity and conclusions, and rather resorted to admonishing the ecclesiastic leadership.

After berating communal leaders for their reticence, Isaacs lambasted them for remaining on summer holiday and refraining from confronting the issue. In 'Congregation's Duty', Isaacs repeats that 'our County Medical Society has been called to the evil consequences of the rite of circumcision performed by incompetent and improper persons', and he then proceeds to provide solutions. ${ }^{57}$ Since 'the life and happiness of very many is imperiled by neglect to inform the public who are to be trusted as officiants', Isaacs suggests that each congregation hastily provide congregants with worthy mohalim 'whom the trustees cheerfully recommend'. ${ }^{58}$ This final article served as Isaacs's appeal to his colleagues to 'save children from [the] danger [of] attending an unskilful operation by a person unfit and unworthy'. Although The Jewish Messenger repeatedly appealed to communal leaders to address the lack of religious supervision which allegedly led to the malpractice of circumcision, no subsequent newspaper reports indicate whether policies were drafted by the Jewish community in response to the city's investigation.

\section{Immigration and the Tides of Change}

Even though The Jewish Messenger valiantly assumed the mantle of leadership and rallied for reform, questions remain about the Jewish response. Why did other periodicals not respond, and why did The Jewish Messenger unflinchingly accept the Board of Health's rejected hypotheses speculations?

\footnotetext{
55 Samuel Myer Isaacs, 'Religious Wrongs', The Jewish Messenger, 20 June 1873, 4.

56 Samuel Myer Isaacs, 'Religious Supervision', The Jewish Messenger, 27 June 1873, 4.

57 Samuel Myer Isaacs, 'Congregation's Duty', The Jewish Messenger, 27 June 1873, 4.

58 Isaacs, 'Religious Supervision', op. cit. (note 56).
} 
Within two decades of the 1873 investigation, the population of New York Jewry increased tremendously. From 1881 until the start of World War I in 1914, two million Eastern European Jews immigrated to the US, of which between 70-90\% settled in New York. ${ }^{59}$ Thus, from an estimated population of 260,000 Jews nationally in 1880, seven years after the metzitzah b'peh-related outbreak, to the end of the subsequent influx of immigrants in 1920, 3450000 Jews resided in America. ${ }^{60}$

Prior to the surge in immigration, the Lower East Side's Jewish Eastern European immigrant community lacked oversight of religious functionaries, including properly trained mohalim. ${ }^{61}$ In contrast to scientifically inspired European reform, in 1873 the American rabbinate did not promote a scientifically sound circumcision protocol. In fact, in 1871, after conceding 'that no one has a greater respect than myself for all religious observances', Dr Charles Russel, New York Health Department's Chairman of Committee on Diseases and Register of Records, admonished New York Jewry for not being vigilant in the training of mohalim. ${ }^{62}$ Russel reported that, 'Some half dozen deaths have occurred in this city from haemorrhage after circumcision of Hebrew infants' and 'numerous unskilled and unscrupulous persons have taken to performing this operation among the poor Jews. I write to beg that you call attention of those having authority in your denomination to so unwarrantable a sacrifice of human life' ${ }^{63}$ Russel's words ultimately fell on deaf ears, since two years later when listening to Taylor present his findings, Russel reiterated that 'malpractice [is] common among the poorer Jews' due to 'a class of ignorant and clumsy operators who make a special business of circumcision'. ${ }^{64}$ The dearth of properly trained mohalim is indicative of the disarray of this burgeoning immigrant population prior to the surge of immigration that would shortly ensue.

Even before the turn of the twentieth century, physicians recognised that an assessment of the 1873 outbreak must be considered in its historical context. For instance, in 1895 one Lower East Side Jewish physician reviewed Taylor's 1873 report and concluded that 'mortality of infants following circumcision twenty-two years ago, was small in comparison with that, commencing in 1881, when the Hebrew population of New York City began to increase greatly'. ${ }^{65}$

During the epochal immigration of Eastern European Jews which commenced in 1881, the established Jewish aristocracy in New York felt compelled to affirm their patriotism and cultural superiority in light of the influx of their provincial and uncouth coreligionists. ${ }^{66}$ In the late nineteenth and early twentieth centuries, Uptown Jews expressed their contempt for their 'gruff-mannered Eastern Europeans' in their German and English periodicals. ${ }^{67}$ The American Hebrew, the successor to the once conservative The Jewish Messenger, was one such paper that vociferously promulgated these chauvinistic myths and premonitions. ${ }^{68}$

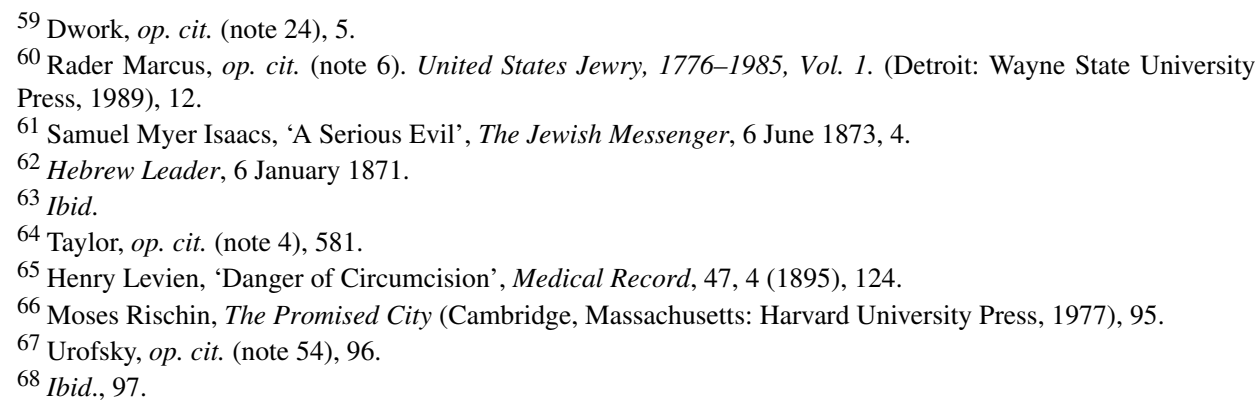


However, at the time of Taylor's inquiry, Jewish immigration had not increased and the established New York Jewish community was not threatened by coreligionists who would undermine their upward mobility and acculturation. ${ }^{69}$ Therefore, in 1873 the Anglo-Jewish newspapers did not attempt to dissociate themselves from the vulnerable community, and did not denigrate or demonise Jewish rite and ritual. However, by 1894 New York's medical community, and its Jewish members in particular, returned their attention to the hygiene of mohalim, prompting one defender of the rite to assert that circumcision had become 'the bete noire of our progressive Hebrew physicians imbued with the spirit of Listerism' ${ }^{70}$ However, in 1873 ritual circumcision had not yet fallen into disrepute and the representatives of the Jewish community were not compelled to come to its defence.

New York Jewry's reticent response to the inquiry must also be appreciated by considering the European milieu with which these immigrations were familiar. In contrast to the American medical establishment's observation that syphilis befell the Jewish community less frequently than other groups, in Europe, for centuries, anti-Semitic thought dominated the discussion of the dissemination and aetiology of syphilis. As early as 1492, accounts indicate that Europeans referred to syphilis as 'the Peste of the Marranos'. ${ }^{71}$ This notion persisted through the twentieth century, as it featured prominently in Hitler's Mein Kampf, wherein he referred to his fear of Jews tainting the Aryan race as the 'syphilization (sic) of our national body'. 72

Paradoxically, this fear was augmented by a common belief that centuries of exposure immunised Jews to syphilis who thenceforth sought to spread it. ${ }^{73}$ With the acceptance of germ theory and popularity of virology in nineteenth century Central European, the European perception of syphilis had changed such that it was considered 'the story of unnatural selections by progenitors who passed on their taint with their germ plasm, eventually resulting in a population of unit monsters'. ${ }^{74}$ Since nineteenth century European medicine deemed integumentary study unsightly, dermatology became one of a few fields available to Jewish physicians and was even referred to as Judenhaut: Jew skin. ${ }^{75}$ As Jewish physicians were on the vanguard of syphilis treatment and research, the anti-Semitic aetiology of syphilis was promulgated.

Circumcision also featured prominently in the scurrilous syphilitic theory, as popular thought assumed that circumcision was required because of Jews' unhygienic, syphilitic disposition. ${ }^{76}$ Moreover, metzitzah b'peh exemplified the perverse, unhygienic and antiquated disposition of the vilified Jew. Consistent with the European focus on hygiene, fear of syphilis and contempt for circumcision, nineteenth-century European

\footnotetext{
69 Ibid., 95.

${ }^{70}$ R. Hochlerner, 'Circumcision - Do We Need Legislation for it: To the Editor of the Medical Record', Medical Record, 26, 22 (1894), 702.

${ }^{71}$ Cited by Harry Friedenwald, The Jews and Medicine: Essays (Baltimore, Maryland: The Johns Hopkins University Press, 1944), 2: 531. Cited in Sander L. Gilman, The Jew's Body (New York: Routledge, 1991), 96.

72 Adolf Hitler, Mein Kampf: Complete, Unabridged and Fully Annotated. John Chamberlain (ed.) (Boston: Houghton Mifflin Company, 1941), 339.

73 Gilman, op. cit. (note 71), 98.

74 Jay Geller, The Other Jewish Question: Identifying the Jew and Making Sense of Modernity (New York: Fordham University Press, 2011), 89-91.

75 Ibid., 96.

76 Armand Louis Joseph Beraud, Etude de Pathologie Comparee: Essai sur la pathologie des semities (Bordeaux: Paul Cassignol, 1897), 55; quoted in Gilman, op. cit. (note 71), 91.
} 
governments mandated hygienic standards for ritual circumcision. As early as 1799 , the Prussian government mandated that only government-appointed mohalim who obtained authorisation from the district physician to testify to their expertise could practise. ${ }^{77}$ Twenty-six years later, the Hamburg municipality adopted the same laws, and added that the mohel must be 'an upstanding citizen of good character'. ${ }^{78}$ Such 'good character' or 'ethical' addenda were mandated by governments who were concerned that Jewish practitioners transmitted venereal diseases. ${ }^{79}$ Despite the extensive government oversight in Europe, when focusing on American legislation, it was not until 1895 that American officials considered employing medico-legal oversight to ritual circumcision. ${ }^{80}$

In the beginning of the nineteenth century, as Central European Jewry gained entrance to universities, the perception of religion and especially circumcision and metzitzah b'peh changed amongst segments of European Jewry, in ways unseen in America. Newly trained Jewish physicians and scientists adopted 'the aesthetic tastes and values of the non-Jewish environment', and adopted the opinion that metzitzah b'peh was aesthetically repulsive and contradictory to modern medical sensibilities. ${ }^{81}$ Upon returning to the synagogue armed with sophisticated medical knowledge, the educated would view the mohel with contempt, as a 'medically unenlightened and intellectually backward' religious functionary. ${ }^{82}$ This sentiment became pervasive and eventually the German Jewry sought to incorporate modern medicine into the rite of circumcision to differentiate themselves from their backwater Eastern European brethren. ${ }^{83}$

While some European Jews reformed Jewish ritual to confirm to contemporary sensibilities, in response the pervasive excitement of medical advances, by the midnineteenth century, even traditionalist segments of western and eastern European Jewry sought to ensure that circumcision complied with modern hygienic and surgical protocols. ${ }^{84}$ For instance, between 1840 and 1880, the Hamburg Jewish community stipulated and enforced that mohalim must 'maintain personal hygiene, clean [their] instruments, utilize fresh bandages' and abstain from operating when ill, and by the latter half of the century, the some municipal rabbinate councils furnished mohalim with kits containing 'antiseptic solutions, sterile knives, and alcohol' ${ }^{85}$ Recognising the need for reform, European rabbinic boards mandated progressive initiatives and provided appropriate medical, ethical, and religious guidance and supervision, while their American counterparts lacked an accountable regulating body to offer such advice. ${ }^{86}$

In America however, prior to 1880, most American physicians still embraced the 'the miasma theory, which equated infection with atmospheric impurity', and only after

\footnotetext{
77 Joseph H. Bloom, Brith Olam (New York: Futuro Press, 1950), 26.

78 Robin Judd, 'Circumcision and Modern Jewish Life: A German Case Study, 1843-1914', in Elizabeth Wyner Mark (ed.), The Covenant of Circumcision (Hanover, NH: Brandeis University Press, 2003), 151.

${ }^{79}$ Sander L. Gilman, Freud, Race, and Gender (Princeton, New Jersey: Princeton University Press, 1993), 66; Geller op. cit. (note 74), 103.

${ }^{80}$ Levien, op. cit. (note 65), 124; Hochlerner, op. cit. (note 70), 702.

${ }^{81}$ Katz, op. cit. (note 50), 364.

82 Judd, op. cit. (note 78), 148.

83 John M. Efron, Medicine and the German Jews (New Haven, CT: Yale University Press, 2001), 189.

${ }^{84}$ Charles Weiss, 'A Worldwide Survey of the Current Practice of Milah (Ritual Circumcision)', Jewish Social Studies, 24, 1 (1962), 32

85 Judd, op. cit. (note 78), 155.

${ }^{86}$ Isaacs, op. cit. (note 61), 4.
} 
1880 did 'all right-minded physicians accepted the germ theory of specific contagion' ${ }^{87}$ In fact, in his 1874 introductory address to Long Island College Hospital, Dr Jarvis Wight dismissed germ theory as myopic, since 'we must not put a part for the whole. Disease results from a variety of causes, and the widest generalization gives us the best definition' ${ }^{88}$ Most notably, the 1882 denunciation of germ theory by 'the grand old man of New York medicine', Dr Alfred Loomis, who proclaimed to students at Bellevue Hospital Medical College that 'people say there are bacteria in the air, but I cannot see them', exemplifies the obstinacy of nineteenth century American medicine. ${ }^{89}$

In light of these differences in scientific advancement, nineteenth-century American medical education was subpar and inadequate compared with European academia. In fact, American physicians recognised that Europeans 'have more science on the other side of the ocean', and as a result of this disparity American 'medical schools make a legion of doctors every year; some are qualified, and some are not', and conceded that 'the standard of medical examinations is not high enough'. ${ }^{90}$ Some also took umbrage with the American curriculum's insufficient instruction in hygiene. For instance, The Sanitarian criticised this deficiency and hoped that if medical schools taught hygiene per se, and insisted upon their graduates being posted in the principles of sanitary science, officers of health would at least have the merit of being sanitarians'. ${ }^{91}$ In reality, the state of American medical education in 1873 was such that 'the rays of sanitary light [were] still very diffuse, [with] a few rays coming from each department of medical instruction'. ${ }^{92}$

Similarly, American public health agencies were not as robust as their European counterparts, and by 1874 , despite the worldwide cholera epidemic of the previous year, only seven states had boards of health. ${ }^{93}$ In fact, the Metropolitan Board of Health for New York City was only established in 1866 following damning municipal sanitary reports as well as the increase in cholera in Europe. ${ }^{94}$ In comparison with European standards, the lax hygienic protocols of American medicine prevented it from adequately responding to the demands of nineteenth-century urbanisation, and thereby created an environment where public health risks remained unaddressed.

By the 1870s the Jewish American press also called for increased vigilance in cleanliness and hygiene. For instance, The Jewish Messenger adopted the messages of the contemporary public health by alerting that 'The moral laws and laws of health are written side by side in the book of God. The same page that tells us to be holy onto our God, not to steal and not to lie, tells us that ablutions are necessary, and that they must be religiously observed'. ${ }^{95}$ The editors appreciated the deplorable living conditions of some of their readers, and contended that:

Many a poor, hard working man cannot procure a sufficient and constant supply of wholesome food and proper clothing, and he may wish in vain for the sweet rest demanded by nature as respite from toil and harassing cares. ... But there is one greater safeguard against disease; there is one preserve of health and

${ }^{87}$ Nancy Tomes, 'The private side of public health: sanitary science, domestic hygiene, and the germ theory, 1870-1900,' Bulletin of the History of Medicine, 64, 4 (1990), 514.

88 Jarvis S. Wight, 'The Relations of Hygiene to Practical Medicine', Sanitarian, 2, 2 (1874), 51.

${ }^{89}$ Markel, op. cit. (note 9), 208.

90 Wight, op. cit. (note 88), 57.

91 Ibid., 56.

92 Ibid.

93 Stephen Smith, 'The Status of Sanitary Science in the United States', Sanitarian, 2, 9 (1874), 417.

94 Dwork, op. cit. (note 24), 9.

95 Samuel Myer Isaacs, 'The Law of Cleanliness', Jewish Messenger, 5 April 1871: 5. 
strength, which can be purchased without wealth, which is independent of time and place, and for the neglect of which there can be no excuse. None need ever transgress the laws of cleanliness. Soap is no article of luxury, and water is the cheapest thing on earth.... Yet there are many who deny themselves the free use of the gift which nature has so bountifully supplied. ${ }^{96}$

As The Jewish Messenger deemed it necessary to warn their readers of the perilous fate of those who ignore sanitary guidelines, it becomes evident that the Jewish press also recognised and were repulsed by the inferior living conditions and habits of some indigent New York Jews.

While Nativist feelings would later surge and anti-Semitism would invariably hamper some Jewish immigrants attempts at upward mobility, the deep-seated resentment which typified centuries of European Christian-Jewish relationships were absent from the American Weltanschauung. American popular thought was not entrenched in centuries of indoctrination which associated syphilis with Judaism and circumcision, and therefore the New York Jewish community sensed that they were not threatened and considered the investigation as a genuine inquiry. In America these immigrants were no longer associated with venereal diseases, and their religious rites would no longer be vilified. Having emigrated from Eastern Europe, many of these immigrants, either in Europe or America, were not exposed to, or at least not entrenched in, the vituperative, anti-traditionalist rhetoric of Central and Western Europe. In addition, the slowly evolving American medical establishment did not avidly promote germ theory. Had germ theory been an accepted tenet of medicine, one would have expected a more scrupulous examination and a more vociferous pronouncement of the risk of metztizah b'peh. Cumulatively, Taylor's investigation and the factors which influenced the Jewish community's response to Taylor, serve as a microcosm of Jewish immigration to America in this time period, as in the land of opportunity immigrants were freed from biases and limitations which had stymied them for centuries, and were faced with the challenges of acculturation and adjustment to American culture and democracy. 